\title{
Pathophysiology of Acute Acid Injury in Rabbit Esophageal Epithelium
}

\author{
Roy C. Orlando, Don.W. Powell, and Charles N. Carney, Departments of \\ Medicine and Pathology, University of North Carolina School of Medicine, \\ Chapel Hill, North Carolina 27514
}

\begin{abstract}
A B S T RA C T To increase our understanding of the pathophysiology of reflux esophagitis, we sought the early sequence of changes in mucosal structure and function in acutely acid-damaged rabbit esophagus. Using a perfused catheter technique esophageal potential difference (PD) profiles were obtained in anesthetized rabbits before, during, and after perfusion of the lower one-half of the esophagus with phosphatebuffered saline or $80 \mathrm{mM} \mathrm{HCl}-80 \mathrm{mM} \mathrm{NaCl}$. When acid perfusion reduced the lower esophageal PD by $40-50 \%$ or $80-100 \%$ of the initial values, the esophagus was removed, sectioned, and the mucosa studied with light microscopy, transmission electron microscopy, and Ussing chamber technique for evaluation of sodium and mannitol transport. The earlier stage of acid damage (PD $\downarrow 40-50 \%$ ) was associated with reduced mucosal resistance from $2,180 \pm 199$ to $673 \pm 157 \mathrm{ohm}$ $\cdot \mathrm{cm}^{2}$ and increased passive transport of sodium $\left(0.10 \pm 0.06\right.$ to $\left.1.82 \pm 0.48 \mu \mathrm{eq} / \mathrm{h} \cdot \mathrm{cm}^{2}\right)$ and mannitol $\left(0.008 \pm 0.003\right.$ to $\left.0.051 \pm 0.012 \mu \mathrm{M} / \mathrm{h} \cdot \mathrm{cm}^{2}\right)(\ddot{P}<0.05)$.
\end{abstract} There was no significant change in short circuit current $(0.35 \pm 0.05$ to $0.35 \pm 0.04)$ or net sodium transport $(0.32 \pm 0.06$ to $0.37 \pm 0.12)$ at this stage, and the only morphologic finding was dilated intercellular spaces on electron microscopy. The later stage of acid damage (PD $\downarrow 80-100 \%)$ exhibited a further reduction in resistance to $299 \pm 65 \mathrm{ohm} \cdot \mathrm{cm}^{2}(P<0.05)$, a finding now accompanied by a reduction in short circuit current $\left(0.35 \pm 0.05\right.$ to $\left.0.21 \pm 0.04 \mu \mathrm{eq} / \mathrm{h} \cdot \mathrm{cm}^{2}\right)$ and complete inhibition of net sodium transport $(0.32 \pm 0.06$ to 0.01 $\pm 0.13)(P<0.05)$. Morphologic studies at this time revealed cellular necrosis, edema, and vesicle formation in the stratum spinosum. Both gross mucosal changes and transmural necrosis were notably absent. When esophageal perfusion was performed with a combination of acid ( $80 \mathrm{mM} \mathrm{HCl}-80 \mathrm{mM} \mathrm{NaCl})$ and pepsin $(100 \mu \mathrm{g} / \mathrm{ml})$, the morphologic and physiologic findings were essentially the same as with acid alone; however, the time of perfusion to reach either the 50 or $100 \%$

Received for publication 18 September 1980 and in revised form 11 March 1981. reduction in $\mathrm{PD}$ was shortened. The findings in this model can be explained on an initial increase in cellular and/or paracellular permeability followed by inhibition of active sodium transport. The resulting loss of osmolar regulation leads to cell necrosis in the stratum spinosum.

\section{INTRODUCTION}

Since the initiating event in the pathogenesis of esophagitis in man is the reflux of gastric contents into the esophagus, most investigations have focused attention on the mechanical barriers to reflux (especially, the lower esophageal sphincter), the character of the refluxed material (hydrochloric acid, pepsin, bile salts, etc.), and esophageal acid clearance $(1,2)$. The response of the esophageal mucosa to noxious substances and in particular to hydrochloric acid $(\mathrm{HCl})$ has also been investigated $(3-11)$. However these studies attempted to clarify the mechanism of acid injury to the mucosa by measuring the lumenal disappearance of hydrogen ion $\left(\mathrm{H}^{+}\right)$, an indirect indicator of tissue damage, and/or by assessing the histology of the injury at one point in time. In our view, the pathogenesis of esophagitis can best be understood by studying the sequence of changes in esophageal mucosal morphology and physiology (e.g. sodium transport) (12) as a result of exposure to $\mathrm{H}^{+}$. For this reason, we developed a model of progressive acid damage in the stratified squamous epithelium of the rabbit esophagus. The details of the morphologic study are in press elsewhere. ${ }^{1}$ In the present study, we describe the physiologic alterations produced by $\mathrm{H}^{+}$alone and with pepsin and correlate them with changes in morphology. In addition, since there has been renewed interest in the use of esophageal potential difference (PD) ${ }^{2}$ measure-

\footnotetext{
${ }^{1}$ Carney, C. N., R. C. Orlando, D. W. Powell, and M. Dodson. Morphologic alterations in acute acid-induced epithelial injury in rabbit esophagus. Lab. Invest. In press.

${ }^{2}$ Abbreviations used in this paper: $\mathrm{I}_{\mathrm{sc}}$, short-circuit current; $J_{\text {net }}^{\mathrm{Na}}$, net sodium transport; $\mathrm{J}_{\mathrm{sm}}^{\mathrm{Na}}$, passive sodium transport; LES, lower esophageal sphincter; m, mucosal; PBS, phosphate-buffered saline; PD, potential difference; $R$, resistance; s, serosal.
} 
ments for the detection of esophageal mucosal disease in man (13-15), we investigated the relationship between an altered in vivo PD and alterations in esophageal morphology and physiology.

\section{METHODS}

In vivo experiments. All studies were performed on male New Zealand albino rabbits weighing 3-5 kg. Rabbits were anesthetized with an intravenous injection of a 1:1 mixture of diazepam $(5 \mathrm{mg} / \mathrm{ml})$ :pentobarbital $(65 \mathrm{mg} / \mathrm{ml})$ and maintained with small periodic doses of anesthetic. After a midline abdominal incision, the esophagogastric junction was located and a cannula placed in the gastric cardia for drainage of esophageal perfusate. The animals, strapped supine to an animal board, were then positioned with their heads elevated $30^{\circ}$. A double lumen polyvinyl catheter assembly (ID $1.1 \mathrm{~mm}$ ) with $1-\mathrm{mm}$ lateral sensing orifices located $3 \mathrm{~cm}$ apart was passed by mouth into the esophagus. The distal orifice was adapted to simultaneously record PD and pressure by a previously described Ringer-perfused catheter technique (16). In brief, intraluminal pressures at the perfused distal orifice were transmitted to an external transducer (model $1280 \mathrm{C}$, HewlettPackard Corporation, Palo Alto, Calif.) and graphed on a Hewlett-Packard (model 7758 A-8 channel) recorder at a paper speed of $1 \mathrm{~mm} / \mathrm{s}$. PD measurements were recorded from the distal orifice by perfusion with a lactated Ringer solution using a plastic syringe driven at $1.1 \mathrm{ml} / \mathrm{min}$. The plastic cap of the distal pressure transducer was modified to allow insertion of a polyethylene tube (PE 280) filled with $4 \%$ agarlactated Ringer solution. The reference PD bridge was a subcutaneous 19-gauge scalp-vein needle with attached tubing (E-Z set 19 infusion set, Deseret Pharmaceutical Co., Inc., Sandy, Utah) that was also filled with lactated Ringer-agar. The free ends of both agar bridges were placed in beakers containing saturated $\mathrm{KCl}$ solution and matched calomel reference electrodes (calomel reference electrodes, porous ceramic junction, Fisher Scientific Co., Pittsburgh, Pa.). The offset potential between electrodes was $<1 \mathrm{mV}$ and this was checked before and after each experiment. Both electrodes were connected to a high impedance $\left(10^{12} \mathrm{ohm}\right)$ bioelectric amplifier and the signal passed through a filter (from the University of North Carolina School of Medicine, Department of Electronics) to the medium gain electrical amplifier (model $8802 \mathrm{~A}$ ) of the Hewlett-Packard recorder.

Since it has been shown that the measurement of esophageal PD can be useful for detecting mucosal injury $(6,13,15,17)$, the in vivo esophageal PD was monitored before, during, and after perfusion of the lower esophagus with acid or acid-pepsin solution. Initially, a preperfusion PD-pressure profile of the esophagus was recorded by gradual withdrawal of our catheter assembly from the gastric cardia to the upper esophageal sphincter. Then, the catheter assembly was fixed so that the PD sensor (distal catheter orifice) could monitor the PD $3 \mathrm{~cm}$ above the lower esophageal sphincter (LES), while allowing perfusion of the lower $6 \mathrm{~cm}$ of esophagus through the orifice of the proximal catheter. An acid solution $(\mathrm{HCl})$ containing $80 \mathrm{mM} \mathrm{HCl}-80 \mathrm{mM} \mathrm{NaCl}(\mathrm{pH}=1.6,288$ mosmol/ $\mathrm{kg} \mathrm{H}_{2} \mathrm{O}$ ) was used for all acid perfusion studies and pepsin $100 \mu \mathrm{g} / \mathrm{ml}$ was added to it for acid-pepsin studies. Phosphate-buffered saline (PBS) $(\mathrm{pH}=7.4,281 \mathrm{mosmol} / \mathrm{kg}$ $\mathrm{H}_{2} \mathrm{O}$ ) was perfused in control animals. All perfusions were carried out at a pump rate of $1.1 \mathrm{ml} / \mathrm{min}$. Continuous perfusion of the distal esophagus with acid or PBS was interrupted for brief periods to allow PD recordings through the Ringerperfused distal orifice. Care was taken to ensure that acid was cleared from the esophagus before the PD recordings were obtained. This procedure was continued in acid-perfusion animals until the PD recorded at the distal orifice was reduced to either 50 or $100 \%$ of the initial PD. In the PBSperfused animals no change in $\mathrm{PD}$ occurred so the perfusion was stopped at $1 \mathrm{~h}$. Following perfusion, a PD-pressure profile of the esophagus was performed for comparison to the preperfusion study. The rabbits were then killed with an overdose of sodium pentobarbital. The esophagus was excised from the thyroid cartilage to the gastroesophageal junction, opened longitudinally, inspected for gross lesions, and then pinned mucosal surface down in a paraffin tray containing iced-oxygenated Ringer's solution. The muscle layers were grasped with hemostats, lifted up, and dissected free of the underlying mucosa with a scalpel. This resulted in a preparation consisting of stratified squamous epithelium, the muscularis mucosa, and a small amount of underlying connective tissue. The mucosal preparation was then sectioned so that two strips ( $5 \mathrm{~mm}$ in width) were taken for histology, one from the perfused segment and the other from the proximal part of the nonperfused segment. These strips were mounted on absorbent paper and placed in separate coded bottles of fixative for light and electron microscopy. The remaining mucosa was mounted in the Ussing chamber for in vitro transport studies using two strips (2-cm wide) from the perfused segment of esophagus and one (the most proximal section) from the nonperfused segment as control.

In vitro experiments. All transport studies were carried out in the Ussing chamber whose Lucite half cells had an aperture of $1.13 \mathrm{~cm}^{2}$. The mucosal $(\mathrm{m})$ and serosal $(\mathrm{s})$ bathing solutions were maintained at $37^{\circ} \mathrm{C}$ and were of similar volume and composition: (in millimoles per liter) mannitol 10, $\mathrm{Na} 140$, $\mathrm{Cl} 119.8$, Ca 1.2, $\mathrm{Mg} \mathrm{1.2}, \mathrm{HPO}_{4} 2.4, \mathrm{H}_{2} \mathrm{PO}_{4} 0.4(280 \mathrm{mosmol} /$ $\left.\mathrm{kg} \mathrm{H}_{2} \mathrm{O}\right), \mathrm{pH}=7.4$ when gassed with $95 \% \mathrm{O}_{2}-5 \% \mathrm{CO}_{2}$. These solutions were connected to calomel and $\mathrm{Ag}-\mathrm{Ag} \mathrm{Cl}$ electrodes with agar bridges made up with the solution studied. The electrodes were connected to an automatic voltage clamp (Physiology Instrument Laboratory, Yale University School of Medicine), which corrects for fluid resistance between PD-sensing bridges and provided measurements of PD and short circuit current $\left(\mathbf{I}_{\mathrm{sc}}\right)$. Tissues were continuously short circuited except for a 5-s interval when the open circuit PD was read. Electrical resistance $(R)$ was calculated using Ohm's Law from the open circuit PD and the $I_{s c}$ or the current deflection to imposed voltage. After mounting, a period of stabilization was permitted before radioactive isotopes were added to the $\mathrm{m}$ and/or $\mathrm{s}$ bathing solutions (time zero).

Sodium transport. Since it has been shown that $45 \mathrm{~min}$ is required before steady-state isotope transfer of sodium (Na) occurs (12), a 1-h flux period was measured beginning $45 \mathrm{~min}$ after addition of isotope. After the first flux period, $0.1 \mathrm{mM}$ ouabain was added to both serosal and mucosal sides. After another $45 \mathrm{~min}$ for equilibration, a second 1-h flux was obtained. Simultaneous bidirectional $\mathrm{Na}$ fluxes were determined with ${ }^{22} \mathrm{Na}$ and ${ }^{24} \mathrm{Na}$. Since two strips were mounted and studied from each perfused segment of esophagus, the means of the results were obtained for each animal and used as a single set of data.

Mannitol transport. As another method of studying the passive mucosal permeability during early acid damage, we perfused eight rabbits with PBS for $1 \mathrm{~h}$ and eight rabbits with acid until the PD decreased to $50 \%$ of the initial value. Following death, mucosal strips were prepared and mounted in the Ussing chamber as described above. In the short circuited state, three 1-h mannitol flux measurements were obtained using $\left[{ }^{14} \mathrm{C}\right]$ mannitol and the mean of these values used in analysis.

The methods of isotope counting have been previously described (18) and statistical analyses were performed using 
Student's $t$ test for paired and unpaired samples. The results are given as the mean \pm SEM.

Histology. Coded specimens obtained for light and electron microscopy were fixed in either phosphate-buffered $4 \%$ paraformaldehyde or modified Karnovsky's fixative for $24 \mathrm{~h}$. Tissues for light microscopy were paraffin-embedded, sectioned, and stained with hematoxylin and eosin. Tissues for electron microscopy were postfixed in osmium tetroxide and embedded in Epon. Thick sections, cut $1 \mu \mathrm{m}$, were stained with toluidine blue and examined with a light microscope both as a second mode of histologic study and as a guide for thin sectioning. Thin sections were mounted on grids and examined with a transmission electron microscope (Zeiss EM model 10-A, Carl Zeiss, Inc., New York) at $60 \mathrm{kV}$. Histologic interpretation was performed without knowledge of the location from which the specimen was taken or type of solution used for esophageal perfusion.

\section{RESULTS}

Effect of acid perfusion on in vivo esophageal PD. Using the initial PD value for each animal as a reference point, the percent change in esophageal PD with time of acid perfusion was obtained (Fig. 1). The first 10 min of contact between acid and esophageal mucosa produced a $30 \%$ increase in $\mathrm{PD}(\sim 9 \mathrm{mV}$ more negative) Subsequently, the PD decreased linearly with time, reaching zero in $\sim 1 \mathrm{~h}$. In contrast, esophageal PD did not significantly change during the $1-h$ period of PBS perfusion.

In Fig. 2, the extent and pattern of PD changes induced by acid or PBS perfusion of the lower esophagus are shown. These profiles were obtained by station pull-through from the stomach to upper esophagus before and after perfusion of the lower esophagus by acid or PBS. Fig. 2A shows that a 1-h perfusion with PBS had no effect on the esophageal PD profile. How-

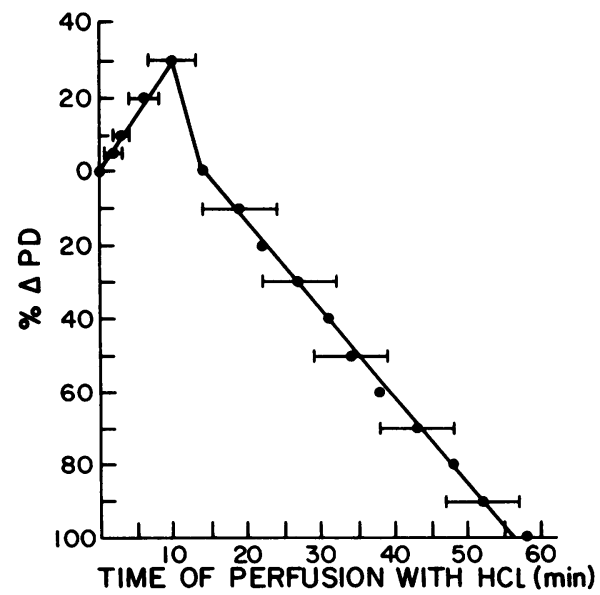

Figure 1 The percent change in esophageal transmural potential difference $(\triangle P D)$ is shown plotted against the time of exposure to $80 \mathrm{mM} \mathrm{HCl}-80 \mathrm{mM} \mathrm{NaCl}$. A transient increase in PD occurs during the first $10 \mathrm{~min}$. This is followed by a progressive linear decline in PD until it reaches zero at $1 \mathrm{~h}$. , Mean $\pm \operatorname{SE}(n=11)$; initial PD $=-30 \pm 2 \mathrm{mV}$.

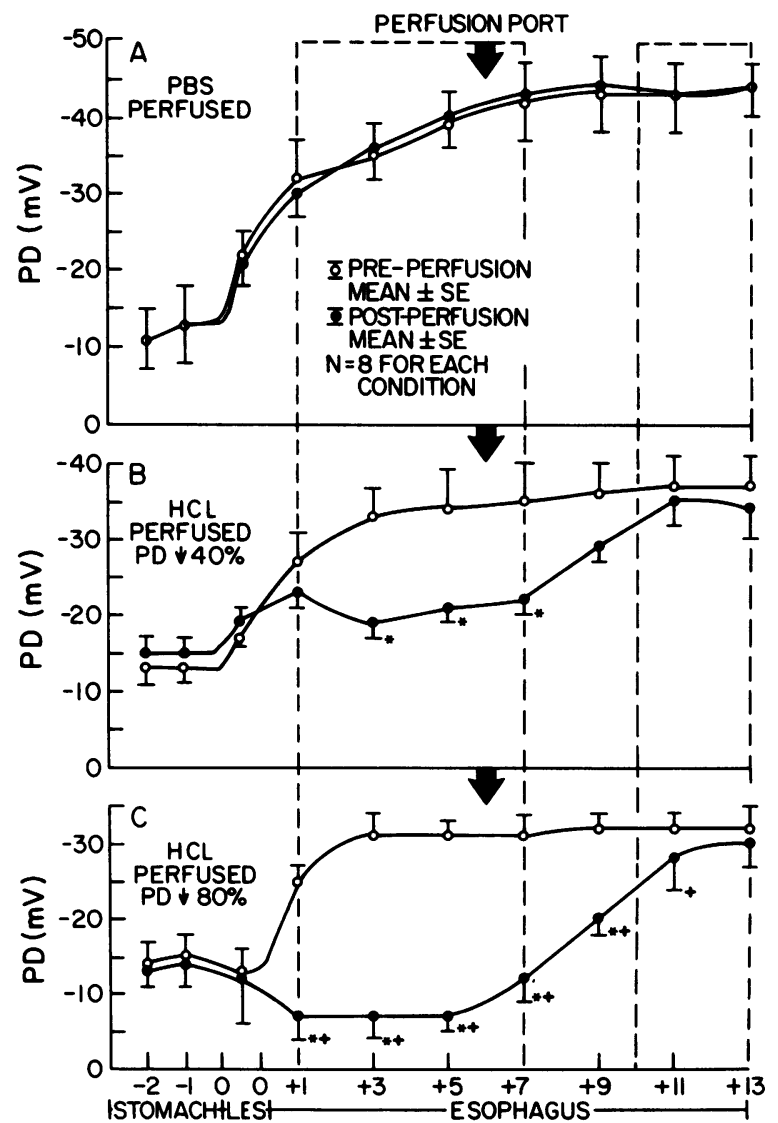

DISTANCE FROM LES $(\mathrm{cm})$

FIGURE 2 The esophageal PD profiles obtained before $(\mathrm{O}-\mathrm{O})$ and after $(-)$ perfusion of the lower $6 \mathrm{~cm}$ of esophagus with (A) PBS, (B) $80 \mathrm{mM} \mathrm{HCl}-80 \mathrm{mM} \mathrm{NaCl}$ until the PD decreased $40-50 \%$ or (C) $80 \mathrm{mM} \mathrm{HCl}-80 \mathrm{mM} \mathrm{NaCl}$ until the PD decreased $80-100 \%$. The large arrow indicates the location of the perfusion orifice. The areas encompassed by the broken lines indicate the location from which mucosal strips were taken for transport and histologic studies. ${ }^{*} P$ $<0.05$ postperfusion $\mathrm{PD}$ vs. preperfusion $\mathrm{PD}$ for same tissue. $+P<0.05$ postperfusion PD for $\mathrm{HCl}$-perfused (PD $\downarrow 40 \%$ ) vs. postperfusion $\mathrm{PD}$ for $\mathrm{HCl}$ perfused $\mathrm{PD} \downarrow$ 80\%).

ever, when acid decreased the recorded PD by $\sim 50 \%$ at the recording site $3 \mathrm{~cm}$ above the LES (mean time of perfusion $30 \pm 3.6 \mathrm{~min}$ ), the postperfusion profile showed an actual average decrease in PD of $40 \%$ for the lower 6-7 cm of esophagus. (Fig. 2B). For animals perfused with acid until the PD decreased $\sim 100 \%$ (mean time of perfusion $68 \pm 6.1 \mathrm{~min}$ ), the postperfusion profile showed an actual decrease in PD of $80 \%$ in the lower 6-7 cm of esophagus (Fig. 2C). In all experiments, the upper half of the nonperfused esophagus (the most proximal one-fourth of total esophagus) showed no alterations in PD; while in acid-perfused animals, the lower half of the "nonperfused" esophagus (adjacent to the perfusion port) demonstrated a PD 
TABLE I

Sodium Transport and Electrical Parameters Obtained In Vitro from PBS-Perfused, $\mathrm{HCl}$

Perfused, and Nonperfused Segments of Rabbit Esophagi*

\begin{tabular}{|c|c|c|c|c|c|c|c|c|c|c|c|c|}
\hline \multicolumn{7}{|c|}{ Nonperfused segments } & \multicolumn{6}{|c|}{ Perfused segments } \\
\hline & $\mathrm{J}_{\mathrm{ms}}{ }^{\mathrm{Na}}$ & $\mathrm{J}_{\mathrm{sm}}{ }^{\mathrm{Na}}$ & $\mathrm{J}_{\text {net }} \mathrm{Na}$ & $I_{s c}$ & PD & $\mathbf{R}$ & $\mathrm{J}_{\mathrm{ms}}{ }^{\mathrm{Na}}$ & $\mathrm{J}_{\mathrm{sm}} \mathrm{Na}^{\mathrm{Na}}$ & $\mathrm{J}_{\text {net }} \mathrm{Na}^{\mathrm{a}}$ & $I_{s c}$ & PD & $\mathbf{R}$ \\
\hline & \multicolumn{4}{|c|}{$\mu \mathrm{eq} / \mathrm{h} \cdot \mathrm{cm}^{2}$} & $m V$ & $\mathrm{ohm} \cdot \mathrm{cm}^{2}$ & \multicolumn{4}{|c|}{$\mu e q / h \cdot \mathrm{cm}^{2}$} & $m V$ & $\mathrm{ohm} \cdot \mathrm{cm}^{2}$ \\
\hline $\begin{array}{l}\text { PBS } \\
\qquad n=8\end{array}$ & $\begin{array}{c}0.41 \\
\pm 0.087\end{array}$ & $\begin{array}{c}0.08 \\
\pm 0.020\end{array}$ & $\begin{array}{c}0.33 \\
\pm 0.092\end{array}$ & $\begin{array}{c}0.32 \\
\pm 0.034\end{array}$ & $\begin{array}{r}-24.1 \\
\pm 1.2\end{array}$ & $\begin{array}{l}2,718 \\
\pm 404\end{array}$ & $\begin{array}{c}0.42 \\
\pm 0.103\end{array}$ & $\begin{array}{c}0.10 \\
\pm 0.060\end{array}$ & $\begin{array}{c}0.32 \\
\pm 0.062\end{array}$ & $\begin{array}{c}0.35 \\
\pm 0.045\end{array}$ & $\begin{array}{r}-21.2 \\
\pm 1.5\end{array}$ & $\begin{array}{l}2,180 \\
\pm 199\end{array}$ \\
\hline $\begin{array}{l}\mathrm{HCl} \\
\quad(\mathrm{PD} \downarrow 40 \%) \\
\quad n=8\end{array}$ & $\begin{array}{c}0.61 \\
\pm 0.253\end{array}$ & $\begin{array}{c}0.23 \\
\pm 0.136\end{array}$ & $\begin{array}{c}0.38 \\
\pm 0.159\end{array}$ & $\begin{array}{c}0.46 \\
\pm 0.106\end{array}$ & $\begin{array}{r}-24.7 \\
\pm 2.7\end{array}$ & $\begin{array}{l}2,213 \\
\pm 310\end{array}$ & $\begin{aligned} & 2.19 t \cdot \S \\
\pm & 0.382\end{aligned}$ & $\begin{aligned} & 1.82 \ddagger \cdot 8 \\
\pm & 0.477\end{aligned}$ & $\begin{array}{c}0.37 \\
\pm 0.123\end{array}$ & $\begin{array}{c}0.35 \\
\pm 0.036\end{array}$ & $\begin{array}{l}-7.21 \cdot 8 \\
\pm 1.8\end{array}$ & $\begin{aligned} & 673 \ddagger \varnothing \\
\pm & 157\end{aligned}$ \\
\hline $\begin{array}{l}\mathrm{HCl} \\
\quad(\mathrm{PD} \downarrow 80 \%) \\
\quad n=8\end{array}$ & $\begin{array}{c}0.45 \\
\pm 0.148\end{array}$ & $\begin{array}{c}0.07 \\
\pm 0.065\end{array}$ & $\begin{array}{c}0.38 \\
\pm 0.076\end{array}$ & $\begin{array}{c}0.39 \\
\pm 0.090\end{array}$ & $\begin{array}{r}-21.1 \\
\pm 2.7\end{array}$ & $\begin{array}{l}2,456 \\
\pm 465\end{array}$ & $\begin{aligned} & 3.74 t \cdot \S^{ل /} \\
\pm & 0.624\end{aligned}$ & $\begin{aligned} & 3.73 t \cdot \S^{\prime \prime} \\
\pm & 0.702\end{aligned}$ & $\begin{aligned} & 0.01 \ddagger \cdot \S \\
\pm & 0.132\end{aligned}$ & $\begin{aligned} & 0.211 \cdot \S^{\prime \prime} \\
\pm & 0.040\end{aligned}$ & $\begin{array}{l}-1.9 ! \cdot \delta^{n} \\
\pm 0.6\end{array}$ & $\begin{array}{l}2991 \cdot 8 \cdot 11 \\
\pm 65\end{array}$ \\
\hline
\end{tabular}

* Values are mean $\pm \mathrm{SE}$; since the perfusion catheter was at mid-esophagus, the upper half (nonperfused segment) of each group served as an additional control.

$\downarrow P<0.05$ compared to PBS-perfused segment.

$\$ P<0.05$ compared to nonperfused segment of same esophagus.

" $P<0.05 \mathrm{HCl}$-perfused (PD $\downarrow 40 \%$ ) segment compared to $\mathrm{HCl}$-perfused (PD $\downarrow$ 80\%) segment.

intermediate between the perfused segment and unaffected portion of nonperfused esophagus.

In vitro studies. The area delineated by the broken lines in Fig. 2 showed the location from which mucosal strips were taken for histology and in vitro transport studies. Two strips were mounted from the segment of esophagus 1-7 cm above the LES and one strip from the area 10-13 cm above the LES. The PD of these strips in vitro paralleled the in vivo PD but at a lower value (approximately two-thirds) and remained stable during the period of flux measurements (up to $105 \mathrm{~min}$ ). After addition of ouabain, the PD decreased steadily, falling to zero by $45 \mathrm{~min}$ in acid-damaged tissue and by $105 \mathrm{~min}$ in PBS-perfused and nonperfused tissue.

Transport studies. Table I shows that the PD, R, $I_{s c}$, and $\mathrm{Na}$ fluxes were similar for all nonperfused strips of esophagus regardless of whether they came from PBS or acid-perfused esophagi. In these strips net sodium transport ( $\mathrm{Jnet}_{\text {net }}^{\mathrm{Na}}$ ) accounted for 100,83 , and $97 \%$ of the $I_{\text {sc }}$ (average 93\%). Similarly, PBS-perfused strips did not differ significantly in $\mathrm{PD}, \mathrm{R}, \mathrm{I}_{\mathrm{sc}}$, or $\mathrm{Na}$ flux from those values in nonperfused strips. As in the nonperfused strips, $J_{\text {net }}^{N a}$ accounted for $91 \%$ of the $I_{s c}$. (Based on previous work from this laboratory, the remainder of the $I_{s c}$ can be accounted for by the active transport of anions $\left(\mathrm{HCO}_{3}{ }^{-}, \mathrm{Cl}^{-}\right)$from serosa to mucosa (12).) Table II shows that ouabain abolished active sodium transport in all tissues. This finding establishes that the low rates of transport measured were real and not below the sensitivity of our technique.

In acid-perfused tissue when the PD decreased by 40-50\%, tissue R decreased by $70 \%$. Passive sodium transport $\left(J_{s m}^{N a}\right)$ increased, but there was no change noted in $J_{\text {net }}^{\mathrm{Na}}$ or $\mathrm{I}_{\text {sc }}$ (Table I). These results suggested that an increase in passive mucosal permeability was a feature of early acid injury. Confirmation of these

TABLE II

Effect of Ouabain on $J_{n e t}{ }^{N a}, P D, I_{s c}$, and $R$ in PBS- and $\mathrm{HCl}$ perfused Segments of Rabbit Esophagi*

\begin{tabular}{|c|c|c|c|c|}
\hline & $\mathrm{J}_{\mathrm{net}}^{\mathrm{Na}}$ & $\mathbf{I}_{\mathbf{s c}}$ & PD & $\mathbf{R}$ \\
\hline & \multicolumn{2}{|c|}{$\mu e q / h \cdot \mathrm{cm}^{2}$} & $m V$ & $\mathrm{ohm} \cdot \mathrm{cm}^{2}$ \\
\hline \multicolumn{5}{|c|}{ PBS $(n=8)$} \\
\hline Before & $0.32 \pm 0.062$ & $0.34 \pm 0.045$ & $-21.2 \pm 1.5$ & $2,180 \pm 199$ \\
\hline After & $0.08 \pm 0.090 \ddagger$ & $0.07 \pm 0.011 \ddagger$ & $-5.0 \pm 0.8 \ddagger$ & $2,462 \pm 294$ \\
\hline \multicolumn{5}{|c|}{$\mathrm{HCl}(\mathrm{PD} \downarrow 40 \%)(n=8)$} \\
\hline Before & $0.37 \pm 0.123$ & $0.35 \pm 0.036$ & $-7.2 \pm 1.8$ & $673 \pm 157$ \\
\hline After & $-0.04 \pm 0.123 \ddagger$ & $0.03 \pm 0.009 \ddagger$ & $-1.0 \pm 0.3 \ddagger$ & $950 \pm 244$ \\
\hline \multicolumn{5}{|c|}{$\mathrm{HCl}(\mathrm{PD} \downarrow 80 \%)(n=8)$} \\
\hline Before & $0.01 \pm 0.132$ & $0.21 \pm 0.040$ & $-1.9 \pm 0.6$ & $299 \pm 65$ \\
\hline After & $-0.17 \pm 0.416$ & $0.02 \pm 0.022 \ddagger$ & $-0.2 \pm 0.1 \ddagger$ & $178 \pm 38$ \\
\hline
\end{tabular}

* Values are mean $\pm \mathrm{SE}$.

$\ddagger P<0.05$ from preoubain value. 
TABLE III

Mannitol Transport in PBS- and HCl-perfused (PB $\downarrow$ 40\%)

Rabbit Esophageal Mucosa*

\begin{tabular}{lcccc}
\hline & PD & $\mathrm{R}$ & $\mathrm{J}_{\mathrm{ms}}{ }^{\mathrm{M}}$ & $\mathrm{Pm}$ t \\
\hline & $m V$ & $\mathrm{ohm} \cdot \mathrm{cm}^{2}$ & $\mu M / \mathrm{h} \cdot \mathrm{cm}^{2}$ & $\mathrm{~cm} / \mathrm{s}$ \\
PBS-control, $n=8$ & $-17 \pm 2$ & $2,194 \pm 285$ & $0.008 \pm 0.003$ & $2.2 \times 10^{-7}$ \\
Acid-PD $\downarrow 40 \%, n=8$ & $-6 \pm 1 \S$ & $681 \pm 123 \S$ & $0.051 \pm 0.012 \S$ & $1.4 \times 10^{-6}$ \\
\hline
\end{tabular}

* Values are mean \pm SEM.

\$ Permeability coefficient for mannitol.

$\$$ Significant difference from control, $P<0.05$.

results was sought by studying the mucosal to serosal flux of mannitol, a molecule believed to be transported only via the paracellular pathway. In Table III, mannitol transport and its calculated permeability coefficient are shown to increase six to sevenfold in acidperfused tissue compared with PBS-perfused tissue.

When mucosal exposure to acid was extended until the PD decreased by $80-100 \%$, tissue $\mathrm{R}$ decreased further, accompanied by increased passive $\mathrm{Na}$ transport (Table I). However active sodium transport was now completely abolished. Notably, even though acid damage had reduced the $J_{\text {net }}^{\mathrm{Na}}$ to zero, a significant $\mathbf{I}_{\mathbf{s c}}$ remained. This $I_{\text {sc }}$ appeared to represent an active transport process since ouabain treatment of the tissue (Table II) resulted in its abolition.

Correlations between in vivo PD and in vitro transport parameters: $P D, R$, and $J_{\text {net }}^{N a}$ A correlation of the in vivo $P D$ with in vitro transport properties in our experimental animals should permit a better understanding of the significance of in vivo changes in PD. That is, do changes in in vivo PD reflect altered ion

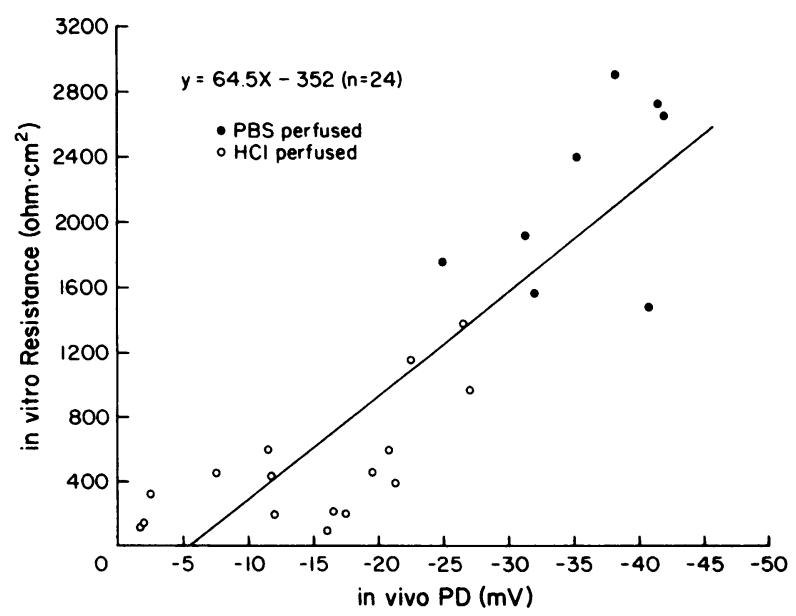

Figure 3 The PD obtained in vivo from the perfused esophageal segments is linearly related to the in vitro resistance of mucosal strips taken from the same areas. $r=0.87, P<0.001$. transport or altered passive permeability? The in vivo PD obtained from the postperfusion esophageal PD profiles (average of PD from 1-7 cm as shown in Fig. 2) were compared to the in vitro PD of the same segments of esophagi (average of PD recorded from 0-105 min after mounting in the Ussing chamber). As expected, the in vitro $P D$ was linearly related to the in vivo $P D$ (in vitro $\mathrm{PD}=0.63$ (in vivo $\mathrm{PD}$ ) $-3.6 \mathrm{mV} ; r=0.87$, $P<0.001)$. The mean in vitro tissue resistance from the same esophagi (0-105 min after mounting) were compared with both the mean in vivo and in vitro PD. A strong linear correlation was found for both. Fig. 3 demonstrates the correlation between in vivo PD and in vitro resistance. These findings contrast with a lack of correlation between in vivo or in vitro $\mathrm{PD}$ and $\mathrm{Jat}$ in these same esophageal segments (not shown, $r=0.33$, $P>0.05$.

Histologic studies. A detailed analysis of the morphologic changes in this model appear elsewhere. ${ }^{1}$ Nonperfused and PBS-perfused segments of esophagus showed no abnormalities on gross inspection, light microscopy, or electron microscopy. However, at an early stage of acid damage (PD decreased by $40-50 \%$ ), the mucosa on electron microscopy demonstrated dilated intercellular spaces. With continued acid perfusion (PD decreased by 80-100\%), both light and electron microscopy showed marked mucosal abnormalities predominantly in the midzone of the stratum spinosum. These abnormalities were characterized by intraepithelial cellular necrosis, edema, and vesicle formation (Fig. 4). Notably even at this stage of acid damage, gross inspection revealed no erosion, ulceration, hemorrhage, or exudate.

Synergistic effects of pepsin. In humans, reflux esophagitis more likely results from combined acidpepsin damage than from acid damage alone. Therefore, the synergism between pepsin and acid was studied by adding pepsin to the esophageal perfusate. The concentration of pepsin used was $100 \mu \mathrm{g} / \mathrm{ml}$ since Goldberg et al. (3) had shown that this dose produces maximal mucosal injury at the concentration of our acid solution $(80 \mathrm{mM} \mathrm{HCl})$. Esophageal perfusion with acid-pepsin, as compared to acid alone, increased the 


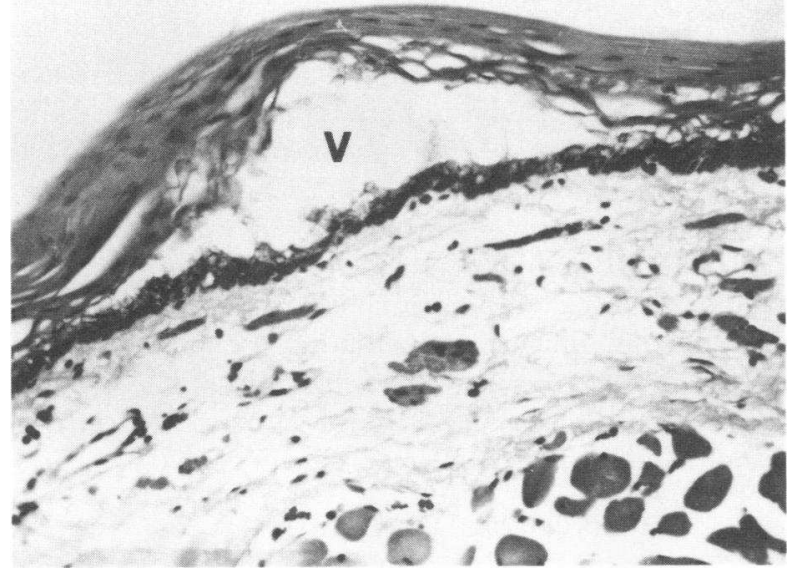

FIGURE 4 Light-micrograph of acid-perfused esophageal mucosa (PD $\downarrow 80-100 \%)$ showing cellular necrosis, edema, and vesicle formation $(\mathrm{V})$ in the mid-zone of the epithelium (stratum spinosum). The stratum corneum and stratum germinativum remain intact. Hematoxylin and eosin stain. $\times 360$.

rate at which the $\mathrm{PD}$ declined to $50 \%(20 \pm 3.1 \mathrm{~min})$ or $100 \%(40 \pm 2.3 \mathrm{~min})$ of the initial values. However, the physiologic changes with acid-pepsin were similar to that for acid alone. Thus, in the $50 \%$ lesion $(n=8)$, the PD $(-13.0 \pm 0.7 \mathrm{mV})$ and $\mathrm{R}\left(800 \pm 59 \mathrm{ohm} / \mathrm{cm}^{2}\right) \mathrm{de}-$ creased significantly while $\mathrm{J}_{\text {net }}^{\mathrm{Na}}(0.33 \pm 0.04 \mu \mathrm{eq} /$ $\left.\mathrm{h} \cdot \mathrm{cm}^{2}\right)$ remained unchanged. In the $100 \%$ lesion $(n=7)$ the PD $(-3.3 \pm 0.4 \mathrm{mV})$ and $\mathrm{R}(311 \pm 69 \mathrm{ohm}$. $\left.\mathrm{cm}^{2}\right)$ further decreased but this was now accompanied by significant inhibition of active sodium transport $\left(J_{\text {net }}^{\mathrm{Na}} 0.14 \pm 0.06 \mu \mathrm{eq} / \mathrm{h} \cdot \mathrm{cm}^{2}\right)$. Also, the histologic alterations produced in acid-pepsin perfused esophagi were essentially the same as those shown for acid damage alone at both the early (PD $\downarrow 50 \%$ ) and late stages (PD $\downarrow 100 \%$ ).

\section{DISCUSSION}

To delineate the early, dynamic changes of acute acid injury to the stratified squamous epithelium of the esophagus, we created a model of acute esophagitis in the rabbit and studied in detail two stages of the process. We chose the rabbit esophagus for our model because $(a)$ the absence of submucosal glands $(12,19)$ enabled us to study the transport properties of the epithelium without interference by glandular secretion and (b) Chung et al. (6) had defined the relationship between $\mathrm{H}^{+}$efflux and changes in PD in this model.

Initially, in vivo acid perfusion of the rabbit esophagus caused a transient increase in the esophageal PD (lumen electrically more negative), a finding similar to that reported in humans (14). Since the junction potential between $\mathrm{HCl}$ and a saline-perfused $\mathrm{PD}$ sensor produces a positive PD (20), this increase can- not be ascribed to a junction potential. Other possible explanations for this initial change could be $(a)$ a $\mathrm{H}^{+}$ diffusion potential, (b) altered epithelial resistance, or $(c)$ stimulated active ion transport. Supporting the latter, increased sodium transport has been observed when frog skin (21), and rabbit urinary bladder (22) were exposed to $\mathrm{H}^{+}$. Nevertheless, continued $\mathrm{H}^{+}$perfusion resulted in a linear decline until the $\mathrm{PD}$ reached zero.

The earliest studies of acid injury were performed when acid reduced the in vivo PD by $40-50 \%$ of the initial value. This in vivo PD change was demonstrable in vitro and was entirely due to a decrease in electrical resistance. Although there was a marked increase in the passive bidirectional $\mathrm{Na}$ flux, net $\mathrm{Na}$ transport, and $I_{s c}$ were unchanged. Thus, physiologically, the first stage of acid damage was an increase in passive permeability. This concept is strengthened by our demonstration of increased mannitol transport at this stage and at a time when Chung and colleagues found an increase in $\mathrm{H}^{+}$efflux (6). Almost identical results have been reported in frog skin exposed to low $\mathrm{pH}(21)$. Morphologically, the changes of early acid "damage" were limited to dilated intercellular spaces on electron microscopy. There was no cellular necrosis or inflammatory cell infiltrate. While no abnormalities of the cell junctions were noted, they may not be detectable without using electron opaque markers $(23,24)$.

The second stage of acid injury studied (PD decreased by $80-100 \%$ ) was characterized by a further decline in PD and tissue resistance. However, in contrast to the earlier stage, complete inhibition of active Na transport was now demonstrated. Morphologically, gross mucosal injury was absent, but damage was characterized by cellular necrosis, edema, and vesicle formation. These findings were primarily limited to the stratum spinosum, with transmural necrosis notably absent. This morphologic appearance suggested that the death of the cells came as a result of swelling and rupture, perhaps due to a loss of osmotic regulatory mechanisms. When acid perfusion is continued beyond this stage, the areas of necrotic cells and vesicular spaces coalesced, undermining the entire upper epithelium. Ultimately, this roof of epithelium sloughed and transmural ulceration occurred. ${ }^{1}$ By the addition of pepsin to the acid perfusion, this entire process was reproduced but at a more rapid rate. Similar histologic findings have been reported by Shirazi and Platz (25) in canine esophagus exposed to solutions of acid and alcohol. More importantly, Gemmel and Stacy (26) have demonstrated a similar lesion in sheep rumen after exposure to hyperosmolarhigh potassium solutions. This suggests that our morphologic findings are not limited to a single injurious agent but may be a more characteristic response to injury of all stratified squamous epithelia. 
The mechanisms by which acid perfusion alters esophageal physiology and morphology are best understood by considering other well studied stratified squamous epithelia such as frog skin and sheep rumen (26-33). In these epithelia, Na passively crosses the dead outer layer (stratum corneum) and into the first living cell layer (stratum granulosum). $\mathrm{Na}$ then disperses through intracellular connections to deeper cells (stratum spinosum) whose low intracellular $\mathrm{Na}$ is maintained by $\mathrm{Na}$ pumps (Na-K ATPase) on their basolateral cell membranes. These pumps transport $\mathrm{Na}$ into the intercellular spaces below tight junctions located in the first living cell layer. While it is likely that similar mechanisms account for $\mathrm{Na}$ transport in esophageal epithelium, a protein lipid material secreted by the cells as membrane-coating granules may be the barrier that seals off the lumen (34).

In our study early acid damage to the esophageal mucosa resulted in dilated intercellular spaces. Further, it has been shown in stratified squamous epithelia that the volume of the intercellular spaces is related to the degree of active $\mathrm{Na}$ transport and to the fluid movement in response to it (35). Thus, in our model, either increased active $\mathrm{Na}$ transport caused a greater water flow through the mucosa or increased epithelial permeability permitted an increase in water flow along an osmotic gradient due to active but unchanged Na transport. Our data favor the latter explanation since mannitol transport increased, whereas active $\mathrm{Na}$ transport remained unchanged.

During the later stage of acid damage (PD $\downarrow 80$ $100 \%$ ), cellular necrosis, edema, and vesicles developed within the epithelium. Although no experimental evidence clearly established why the cell death predominated in the stratum spinosum, it may be due to inhibition of active Na transport. Mills and colleagues (36), using tritiated-ouabain and radioautography, showed that the Na pumps in frog skin are concentrated in the mid- to lower layers of the stratum spinosum. A similar distribution of $\mathrm{Na}$ pumps may be present in the esophageal epithelium. Further, $\mathrm{H}^{+}$can render the cell membrane more permeable to $\mathrm{Na}(21,22)$. Thus, early acid exposure may increase $\mathrm{Na}$ entry into cells and allow $\mathrm{H}^{+}$access to Na pumps of the stratum spinosum. When the concentration of $\mathrm{H}^{+}$becomes sufficiently high, the Na-K ATPase is inhibited (37). As a result, the combination of increased $\mathrm{Na}$ entry with decreased $\mathrm{Na}$ exit from the cells would lead to intracellular edema and ultimately rupture. Under this scheme, the demonstrated inhibition of active $\mathrm{Na}$ transport would be a cause and not an effect of the intraepithelial cellular necrosis.

By correlating in vivo $P D$ with in vitro mucosal function, we showed that a decrease in PD in vivo correlated best with a decrease in tissue resistance. However, as shown by our early stage, the initial phase of acid damage may not be accompanied by light microscopic changes in esophageal histology.

In summary, at the earliest stage of acid damage, there was increased epithelial passive permeability and dilated intercellular spaces on electron microscopy. At the later stage permeability increased further, but now there was inhibition of active sodium transport and cellular necrosis in the stratum spinosum. Although the exact mechanisms responsible for these changes remain to be elucidated, we postulate that $\mathrm{H}^{+}$first increases $\mathrm{Na}$ entry into cells of the stratum spinosum and then, by inhibition of $\mathrm{Na}$ exit, results in loss of osmolar regulation and cell necrosis.

\section{ACKNOWLEDGMENTS}

We are indebted to Judy C. Bryson, Ms. Alyson Adams, and Ms. Myra M. Dodson for their invaluable technical assistance, and Mrs. Sandra F. Woody for expert secretarial help in preparing this manuscript.

This work was supported in part by grant 5R01 AM21873 from the National Institutes of Health.

\section{REFERENCES}

1. Pope, C. E., II. 1976. Pathophysiology and diagnosis of reflux esophagitis. Gastroenterology. 70: 445-454.

2. Dodds, W. J., W. J. Hogan, and W. N. Miller. 1976. Reflux esophagitis. Am. J. Dig. Dis. 21: 49-67.

3. Goldberg, H. I., W. J. Dodds, S. Gee, C. Montgomery, and F. F. Zboralski. 1969. Role of acid and pepsin in acute experimental esophagitis. Gastroenterology. 56: 223-230.

4. Safaie-Shirazi, S., L. DenBesten, and W. L. Zike. 1975. Effect of bile salts on the ionic permeability of the esophageal mucosa and their role in the production of esophagitis. Gastroenterology. 68(4): 728-733.

5. Redo, S. F.. W. A. Barnes, and A. O. De La Sierra. 1959. Perfusion of the canine esophagus with secretions of the upper gastro-intestinal tract. Ann. Surg. 149(4): 556-564.

6. Chung, R. S. K., J. Magri, and L. DenBesten. 1975. Hydrogen ion transport in the rabbit esophagus. Am. J. Physiol. 229(2): 496-500.

7. Henderson, R. D., F. Mugashe, K. N. Jeejeebhoy, J. Cullen, M. Szczepanski, A. Boszko, and G. Marryatt. 1972. The role of bile and acid in the production of esophagitis and the motor defect of esophagitis. Ann. Thorac. Surg. 14(5): 465-473.

8. Lambert, R. 1962. Relative importance of biliary and pancreatic secretions in the genesis of esophagitis in rats. Am. J. Dig. Dis. 7(11): 1026-1033.

9. Ferguson, D. J., E. Sanches-Palomera, Y. Sako, H. W. Clatworthy, R. W. Toon, and O. H. Wangensteen. 1950. Studies of experimental esophagitis. Surgery. 28(6): 1022-1039.

10. Harmon, J. W., L. F. Johnson, and C. L. Magdonovitch. 1980. Do bile salts cause hydrogen ion back diffusion from the rabbit esophagus? Clin. Res. 28: 227A. (Abstr.)

11. Kivilaakso, E., D. Fromm, and W. Silen. 1980. Effect of bile salts and related compounds on isolated esophageal mucosa. Surgery. 87: 280-285.

12. Powell, D. W., S. M. Morris, and D. D. Boyd. 1975. Water and electrolyte transport by rabbit esophagus. Am. J. Physiol. 229(2): 438-443.

13. Khamis, B., C. Kennedy, J. Finucane, and S. Doyle. 1978. Transmucosal potential difference: diagnostic value in gastro-oesophageal reflux. Gut. 19: 396-398. 
14. Eckardt, V. F., and B. Adami. 1980. Esophageal transmural potential difference in patients with symptomatic gastroesophageal reflux. Klin. Wochenschr. 58: 293-297.

15. Kinard, H. B., J. D. Jones, R. C. Orlando, D. W. Powell. 1979. Esophageal potential difference as an indicator of mucosal disease. Gastroenterology. 76: 1169. (Abstr.)

16. Turner, K. S., D. W. Powell, C. N. Carney, R. C. Orlando, and E. M. Bozymski. 1978. Transmural electrical potential difference in the mammalian esophagus in vivo. Gastroenterology. 75: 286-291.

17. Vidins, E. I., J. E. F. Fox, and I. T. Beck. 1971. Transmural potential difference (PD) in the body of the esophagus in patients with esophagitis, Barrett's epithelium and carcinoma of the esophagus. Am. J. Dig. Dis. 16: 991-999.

18. Powell, D. W., H. J. Binder, and P. F. Curran. 1972. Electrolyte secretion by guinea pig ileum in vitro. Am. J. Physiol. 223: 531-537.

19. Boyd, D. D., C. N. Carney, and D. W. Powell. 1980. Neurohumoral control of esophageal epithelial electrolyte transport. Am. J. Physiol. 239: G5-G11.

20. Read, N. W., and J. S. Fordtran. 1979. The role of intraluminal junction potentials in the generation of the gastric potential difference in man. Gastroenterology. 76: 932-938.

21. Fischbarg, J., and G. Whittembury. 1978. The effect of external $\mathrm{pH}$ on osmotic permeability, ion and fluid transport across isolated frog skin. J. Physiol. (Lond.). 275: 403-417.

22. Lewis, S. A., and J. M. Diamond. 1976. $\mathrm{Na}^{+}$transport by rabbit urinary bladder, a tight epithelium. J. Membr. Biol. 28: $1-40$.

23. Martinez, A., D. Erlij, and H. Bracho. 1971. Localization of permeability barriers in frog skin epidermis. J. Cell Biol. 50: $277-287$.

24. Mollgard, K., D. N. Malinowski, and N. R. Saunders. 1976. Lack of correlation between tight junction morphology and permeability properties in developing choroid plexus. Nature (Lond.). 264: 293-294.

25. Safaie-Shirazi, S., and C. E. Platz. 1978. Effect of alcohol on canine esophageal mucosa. J. Surg. Res. 25: 373-379.
26. Gemmel, R. T., and B. D. Stacy. 1973. Effects of ruminal hyperosmolality on the ultrastructure of ruminal epithelium and their relevance to sodium transport. J. Exp. Physiol. 58(4): 315-323.

27. Ussing, H. H., and E. E. Windhager. 1964. Nature of shunt path and active sodium transport path through frog skin epithelium. Acta Physiol. Scand. 61: 484-504.

28. Koefoed-Johnsen, V., and H. H. Ussing. 1958. The nature of the frog skin potential. Acta Physiol. Scand. 42: $298-308$.

29. Moreno, J. H., I. L. Reisin, E. R. Boulan, E. A. Rotunno, and M. Cereijido. 1973. Barriers to sodium movement across frog skin. J. Membr. Biol. 11: 99-115.

30. Farquhar, M. G., and G. E. Palade. 1964. Functional organization of amphibian skin. Zoology. 51: 569-577.

31. Voute, C. L., and H. H. Ussing. 1968. Some morphological aspects of active sodium transport: the epithelium of the frog skin. J. Cell Biol. 36: 625-638.

32. Harrison, F. A., R. D. Keynes, J. C. Rankin, and L. Zurich 1975. The effect of ouabain on ion transport across isolated sheep rumen epithelium. J. Physiol. (Lond.). 249: 669-677.

33. Henrikson, R. C. 1971. Mechanism of sodium transport across ruminal epithelium and histochemical localization of ATPase. Exp. Cell Res. 68: 456-458.

34. Elias, P. M., N. S. McNutt, and D. S. Friend. 1977. Membrane alterations during cornification of mammalian squamous epithelia: a freeze-fracture, tracer, and thinsection study. Anat. Rec. 189: 577-594.

35. Voute, C. L., and H. H. Ussing. 1970. Quantitative relation between hydrostatic pressure gradient, extracellular volume and active sodium transport in the epithelium of the frog skin (R. Temporaria). Exp. Cell Res. 61: 133-140.

36. Mills, J. W., S. A. Ernst, and D. R. DiBona. 1977. Localization of $\mathrm{Na}^{+}$-pump sites in frog skin. J. Cell Biol. 73: $88-110$.

37. Bonting, S. L. 1970. Sodium potassium activated adenosinetriphosphatase and cation transport. In Membranes and Ion Transport. E. E. Bittar, editor. Wiley Interscience, London. 1: 257. 